\title{
Therapeutic alternative for oral lichen planus treatment in an unusual location: case report
}

Alternativa terapêutica para tratamento de líquen plano oral com localização incomum: relato de caso Alternativa terapeutica para el tratamiento de liquen plano oral con localización inusual: reporte de caso Thaís Torres Barros DUTRA ${ }^{\mathbf{1}}$

Thâmara Manoela Marinho BEZERRA ${ }^{2}$

Filipe Nobre CHAVES ${ }^{3}$

Sthefane Gomes FEITOSA ${ }^{1}$

Fábio Wildson Gurgel COSTA 4

Karuza Maria Alves PEREIRA ${ }^{5}$

${ }^{1}$ Doutoranda, Departamento de Patologia Oral, Faculdade de Farmácia, Odontologia e Enfermagem (FFOE), Universidade Federal do Ceará (UFC), 60430-355 Fortaleza - CE, Brazil

${ }^{2}$ Pós-Doutoranda, Departamento de Patologia Oral, Faculdade de Farmácia, Odontologia e Enfermagem (FFOE), Universidade Federal do Ceará (UFC), 60430-355 Fortaleza - CE, Brazil

${ }^{3}$ Professor Adjunto,Mestrado em Ciências da Saúde,Curso de Odontologia,Universidade Federal do Ceará,Campus Sobral, 62010-820 Sobral - CE, Brazil ${ }^{4}$ Professor Adjunto, Departamento de Radiologia Odontológica, Faculdade de Farmácia, Odontologia e Enfermagem (FFOE), Universidade Federal do Ceará (UFC), 60430-355 Fortaleza - CE, Brazil

${ }^{5}$ Professora Associada, Departamento de Morfologia, Faculdade de Medicina (FAMED), Universidade Federal do Ceará (UFC), 60430-160 Fortaleza - CE, Brazil

\section{Abstract}

Oral Lichen Planus (OLP) is considered a potentially malignant lesion (PML), although its rate of transformation is controversial. New treatments have been introduced recently, for example calcipotriene (D3 vitamin analog). Its incremental action with glucocorticoids is observed and isolated lip lesions may respond positively to combined topical therapy. Thus, objective of this case report is to show a therapeutic alternative for isolated and persistent OLP lip lesions. An 18-year-old teenager was referred to evaluate an erythematous lower lip lesion with approximately 10 years of evolution. The inspection revealed multiple erythematous areas surrounded by thin whitish streaks located in the vermilion of the lower lip. No abnormalities in the skin, nails, scalp or other areas of oral mucosa were observed. The incisional biopsy was performed and the microscopic exam showed areas of basal layer degeneration with intense mononuclear inflammatory infiltrate banded and predominantly subepithelial. The therapeutic proposal was topical application of Daivobet $\circledast$, a combination of topical corticosteroids and vitamin $\mathrm{D}$ derivative. The lesion had remission after the fifteen days, medication was suspended and indicated when there was a relapse. During follow-up, no recurrences or complications were observed. That combination therapy may be a new approach in treating OLP.

Descriptors: Lichen Planus; Lichen Planus, Oral; Lip; Pharmaceutical Preparations.

\section{Resumo}

O Líquen Plano Oral (LPO) é considerado uma lesão potencialmente maligna (LPM), embora sua taxa de transformação seja controversa. Novos tratamentos foram introduzidos recentemente, por exemplo, glicocorticóides em combinação ao calcipotriol (análogo da vitamina D3). Lesões labiais isoladas podem responder positivamente a esta terapia tópica combinada, aumentando a efetividade do tratamento. Assim, o objetivo deste relato de caso é mostrar uma alternativa terapêutica para lesões labiais de LPO isoladas e persistentes. Um adolescente de 18 anos foi encaminhado para avaliar uma lesão eritematosa do lábio inferior com aproximadamente 10 anos de evolução. A inspeção revelou múltiplas áreas eritematosas cercadas por finas estrias esbranquiçadas localizadas no vermelhão do lábio inferior. Não foram observadas anormalidades na pele, unhas, couro cabeludo ou outras áreas da mucosa oral. A biópsia incisional foi realizada e o exame microscópico mostrou áreas de degeneração da camada basal com intenso infiltrado inflamatório mononuclear em faixas e predominantemente subepitelial. A proposta terapêutica foi a aplicação tópica de Daivobet $\AA$, uma combinação de tópica de corticoide e calcipotriol. $A$ lesão teve remissão após os quinze dias, a medicação foi suspensa e indicada quando houvesse recidiva. Durante o acompanhamento, não foram observadas recorrências ou complicações. Essa terapia combinada pode ser uma nova abordagem no tratamento do LPO.

\section{Descritores: Líquen Plano; Líquen Plano Bucal; Lábio; Preparações Farmacêuticas.}

\section{Resumen}

El liquen plano oral (LPO) es considerada una lesión potencialmente maligna (LPM), aunque su tasa de transformación sea aún controversial. Recientemente fueron introducidos nuevos tratamientos como ser; glicocorticoides en combinación con calcipotriol (análogo de la vitamina D3). Lesiones labiales aisladas pueden responder positivamente a esta terapia tópica combinada, aumentando la efectividad del tratamiento. Por tanto, el objetivo de este reporte de caso es mostrar una alternativa terapéutica para lesiones labiales aisladas y persistentes de LPO. Se realizó un examen clínico de una lesión de labio inferior con aproximadamente 10 años de evolución en un paciente de 18 años, el cual reveló múltiples áreas eritematosas delimitadas por finas estrías blanquecinas localizadas en el bermellón del labio inferior. No se observaron anomalías en mucosa oral, piel, uñas, o cuero cabelludo. El examen microscópico de la biopsia incisional mostró áreas de degeneración de la camada basal con intenso infiltrado inflamatorio mononuclear em banda predominantemente subepitelial. La propuesta terapéutica fue la aplicación de Daivobet ${ }^{\circledR}$; combinación tópica de corticoide y análogo de la vitamina D3. Luego de quince días las lesiones fueron evaluadas nuevamente constatando remisión de estas, la medicación fue suspendida e indicada cuando se presentase recidiva. Durante el seguimiento del caso no se observaron complicaciones. La combinación de estos componentes puede ser una nueva alternativa para el tratamiento de LPO.

Descriptores: Liquen Plano; Liquen Plano Oral; Labio; Preparaciones Farmacéuticas.

Lichen Planus (LP) is a chronic,
mucocutaneous, immunologically mediated
disease of uncertain etiology ${ }^{1-4}$ which mainly
affects the skin, scalp, nails and mucosa in the
form of itchy papules with fine white lines in the

surface (Wickham striae) ${ }^{5-7}$. Its terminology was given by the British physician Erasmus Wilson in 1869 , possibly due to the similarity of clinical lesions to lichens growing on rocks. In the oral cavity, LP is difficult to diagnose, and clinical 
and histopathological data must be combined, as there are six clinical subtypes of the disease (reticular, plaque-like, atrophic, erosive / ulcerative, papular and bullous) that may manifest in a combined manner, with periods of relapses and remissions ${ }^{4,8}$. In addition, Oral Lichen Planus (OLP) is considered a potentially malignant lesion (PML), although its rate of transformation is controversial ${ }^{9}$. The risk of malignant transformation increases with the presence of erosive and / or atrophic areas, tobacco and / or alcohol consumption, hepatitis $C$ virus infection and when located in the tongue ${ }^{10}$. Due to anatomic, physiologic and functional peculiarities of the oral cavity, OLP requires specific evaluations for diagnosis and management ${ }^{4}$.

Management of OLP involves the treatment of atrophic and erosive / ulcerative lesions to relieve the symptoms as well as to reduce the potential risk of malignant transformation ${ }^{4,11}$. However, the protocol for treating OLP is not well defined ${ }^{11}$. Currently, the use of topical agents is preferred due to the few adverse effects. Topical corticosteroid is the most widely used drug because it has fewer adverse effects and a good patient response rate (between $30 \%$ and $100 \%$ of cases) ${ }^{12,13}$. Other topical agents that can be alternatively used are retinoids, topical aloe vera, biologics, oral curcuminoid, calcineurin inhibitors (e.g., tacrolimus, cyclosporine) and low intensity laser $^{14-16}$.

New OLP treatments have been introduced recently. Calcipotriene, the D3 vitamin analog, was introduced in the United States in 1994 for the treatment of psoriasis vulgaris $^{17}$. Its anti-inflammatory effects are inferior to those provided by glucocorticoids, but an incremental action is observed when the two drugs are combined ${ }^{18}$ and the cutaneous LP disease course seems to be similarly affected by both treatments ${ }^{19}$.

As lip OLP has a clinical course similar to cutaneous LP, isolated lip lesions may respond positively to combined topical therapy of glucocorticoids and calcipotriol. Thus, the objective of this case report is to show a therapeutic alternative for isolated and persistent OLP lip lesions.

CLINICAL CASE

An 18-year-old teenager was referred to the Oral Medicine Clinic to evaluate an erythematous lower lip lesion with approximately 10 years of evolution. The extraoral (Figure $1 \mathrm{~A}$ and $\mathrm{B}$ ) inspection revealed multiple erythematous areas surrounded by thin whitish streaks located in the vermilion of the lower lip. No abnormalities in the skin, nails or scalp were observed. The intraoral inspection shows continuity of lesions located in the vermilion of the lip to the labial mucosa (Figure 1C and D), with no other areas of oral mucosa involved.

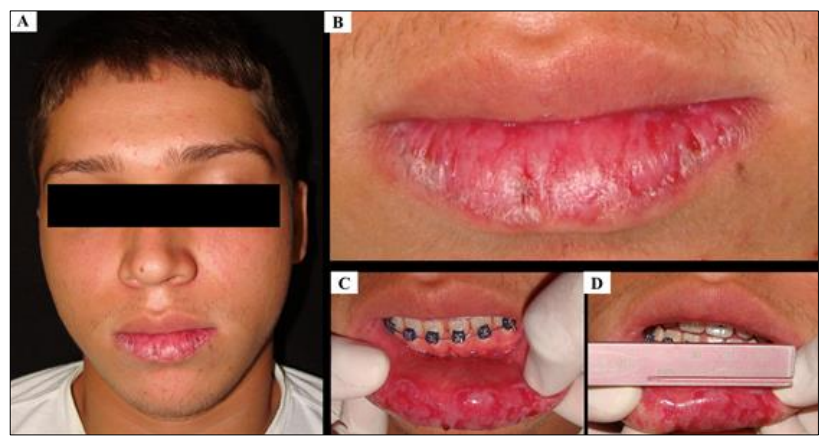

Figure 1: Intra and extraoral aspect of the patient: A. Frontal view with no skin abnormality; B. Zoomed view of the lower lip showing erythematous areas surrounded by thin whitish streaks; $\mathbf{C}$. Evaluation of lower lip vermilion showing erythematous lesions bleeding to the touch; D. Extension of lesions located in vermilion of the lip and there are no other areas of the oral mucosa involved.

The patient reported a burning sensation and mild intermittent pain, worsening when hot or spicy foods were ingested. There were no reports of systemic diseases, general or drug allergies, or use of tobacco or alcohol. In addition, no similar lesions appeared in other regions of the body during the 10 years of lip lesions onset. Several drug therapies (topical corticosteroids, topical antiretrovirals, vitamins (folic acid and B complex) and antibiotics) were previously administered by other professionals, but without remission of the clinical picture. His medical, social and cultural histories were not contributory.

Considering the clinical hypothesis of LP, an incisional biopsy was performed, and the specimen was sent for histologic examination. The specimen was fixed in $10 \%$ neutral formalin buffer and embedded in paraffin. Macroscopic examination revealed 3 soft tissue fragments, predominantly white, of irregular shape and surface, with rubbery and fibrous consistency, the largest fragment measuring $0.7 \times 0.5 \times 0.4$ $\mathrm{cm}$. The microscopic exam showed areas of basal layer degeneration with intense mononuclear inflammatory infiltrate banded and predominantly subepithelial (Figure $2 \mathrm{~A}$ and $\mathrm{B}$ ). The final diagnosis was LP.

The therapeutic proposal was topical application of Daivobet $\AA$, whose formulation contains calcipotriol hydrate $50 \mathrm{mcg} / \mathrm{g}$ and betamethasone dipropionate $0.5 \mathrm{mg} / \mathrm{g}$, a combination of topical corticosteroids and vitamin $D$ derivative. The patient was followed fortnightly and the lesion was remitted after the first fifteen days (Figure 3). The use of medication was suspended and indicated when 
there was a relapse. During follow-up, no recurrences or complications were observed (Figure 4).

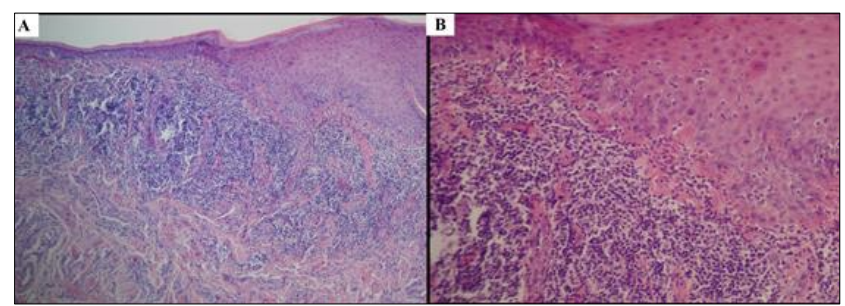

Figure 2: Photomicrographs: A. Oral mucosa lining epithelium showing areas of atrophy and acanthosis. A large banded inflammatory infiltrate is observed on the lamina propria underlying mucosal lining tissue (H / E 100x). B. In greater detail is observed in the epithelium loss of clarity of the basal layer and exocytosis. The underlying lamina propria shows presence of intense lymphocyte inflammatory infiltrate (H / E 200x).

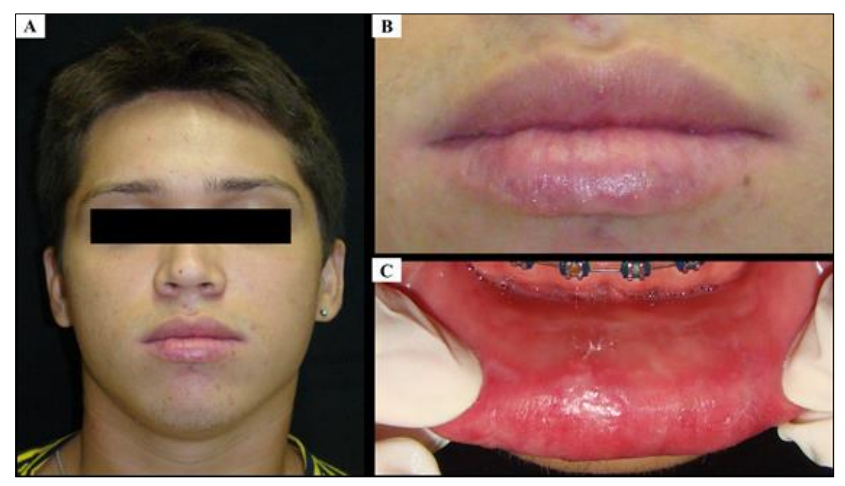

Figure 3. Extraoral and intraoral aspect of the patient after 15 days of Daivobet therapy: A. Frontal view with no skin abnormality; B. Approximate view of the lower lip showing remission of erythematous lesions and whitish striae; C. Evaluation of lower lip vermilion with no other areas of involvement.

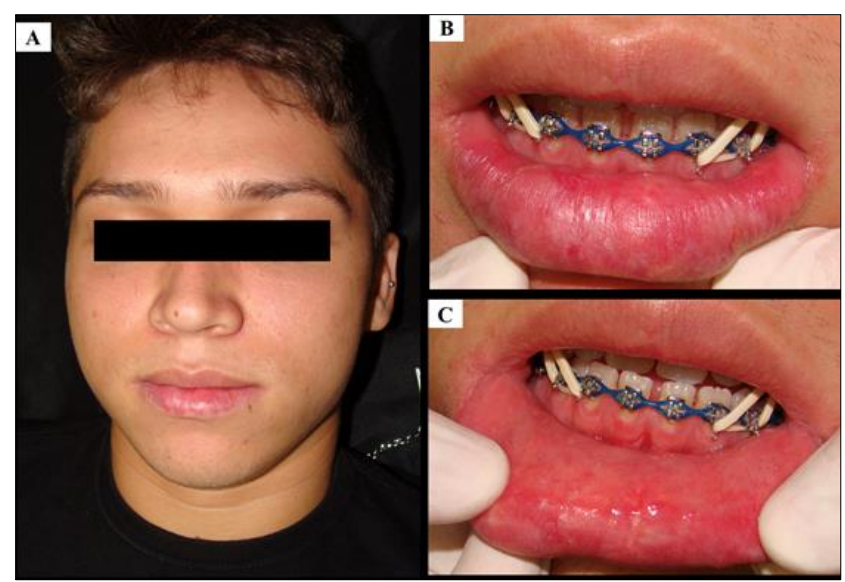

Figure 4: Extraoral and intraoral aspect of the patient during follow-up: A. Frontal view with no skin abnormality; B. Approximate view of the lower lip showing remission of erythematous lesions and whitish striae; C. Evaluation of lower lip vermilion with no other areas of involvement.

\section{DISCUSSION}

Epidemiological studies show a low OLP prevalence in the adult population (estimated at $0.5 \%$ to $2 \%)^{8,20}$. It preferentially affects women aged $30-60$ years and presents itself clinically isolated or associated with cutaneous manifestations ${ }^{14,21,22}$. This case report presents an OLP restricted to the lower lip of a young man. OLPs that strictly affect the lip have a preference for males and are rare ${ }^{23}$. Two studies detected OLP in lip alone, with a prevalence of 6.3 and $8.9 \% \%^{3,23}$. However, when OLP affects other regions of the oral cavity, the lip is commonly affected ${ }^{20,24,25}$.

OLP in lip vermilion has a different clinical aspect from skin LP due to peculiarities of this region, such as: thick squamous epithelium, abundant capillary supply within interdigitating rete ridges and dermal papillae, besides absence of follicular and salivary structures ${ }^{26}$. However, the lesions in the present case showed a classic appearance of an erosive OLP (Figure 1). OLP lesions, especially in the lip, are insidious and easily overlooked because they are asymptomatic in most cases, except for erosive and scarring forms due to severe local pain, lip atrophy and miscrostomy ${ }^{26}$. The patient in this study reported that the lesions were present for 10 years and that no drug therapy was effective until then to eliminate the lesions definitively. In this case, incisional biopsy was an important tool to guide clinical treatment, since with the histopathological diagnosis of OLP associated with the clinical history of multiple treatments without remission, we can better direct the patient's treatment.

OLP etiology is controversial, but there is strong evidence that it is an immunologically mediated disease with antigen-specific and nonantigen-specific mechanisms involved in its pathogenesis ${ }^{27}$. Within the specific mechanisms, antigen expression occurs by basal layer keratinocytes and their consequent death by CD8 cytotoxic T cells. Non-specific mechanisms include mast cell degranulation and metalloproteinase matrix (MPM) activation ${ }^{27}$. The combination of these mechanisms causes $T$ cell accumulation in the underlying lamina propria with consequent disruption of the basement membrane, $\mathrm{T}$ lymphocyte migration towards the epithelium and keratinocyte apoptosis. This process is perpetuated through the release of chemokines in the inflammatory $\mathrm{site}^{27}$. Based on this, corticosteroids, especially glucocorticoids, are the first line of choice in the treatment of OLP.

Midpotency corticosteroids such as triamcinolone, potent fluorinated corticosteroids such as fluocinolone acetonide and fluocinonide as well as superpotent halogenated corticosteroids such as clobetasol have been successfully applied in clinical practice ${ }^{28,29}$. The main form of administration of this drug for treatment of OLP is topical, since it promotes less adverse effects. However, side effects such as secondary candidosis, nausea, non-tolerated oral use, refractory response, mucosal atrophy, oral dryness, sore throat, bad taste, and delayed 
healing have been observed ${ }^{30,31}$.

Calcipotriol (Daivonex / Dovonex) is an indicator of vitamin $D$ and has been used to treat psoriasis vulgaris (PV) in the United States since $1994^{31}$. Vitamin D analogs and topical corticosteroids are likely to have different modes of action. The calcipotriol suppresses lymphocyte proliferation by decreasing interleukin-1 and interleukin- ${ }^{17}$ as well as induces terminal differentiation and inhibits proliferation of keratinocytes ${ }^{32}$. Their antiinflammatory properties are known to be inferior to those of glucocorticoids, but an incremental effect has been observed when these drugs are used in combination to treat $P V^{17,18}$, as there is better efficacy, superior tolerability and faster clinical action compared to individual drug use $^{17,33,34}$. In this case, we believe that calcipotriol when combined with corticosteroids promoted its best efficacy, since the onset of clinical improvement occurred after 14 days of combined use of calcipotriol and betamethasone. It is important to emphasize that the patient did not show improvement in clinical condition with the use of corticosteroids alone.

The safety profiles of calcipotriene and betamethasone as monotherapies are well established $^{35-37}$. Adverse reactions to calcipotriene use are predominantly local and the most common are erythema or increased itchness ${ }^{38,39}$. It is expected that the adverse effects will be similar to the adverse reaction profile of betamethasone, when using the drugs together ${ }^{17}$. However, the patient in this study did not show any adverse effects during the combined therapy period, and there was a satisfactory and similar clinical response to PV patients. Alternative therapies for OLP treatment may be chosen through diseases that also have immune and inflammatory pathogenesis, such as PV.

In addition to the autoimmune nature, other factors are associated with the progression of OLP lesions, such as: allergic reactions to dental restorative agents (amalgam and gold), chronic irritants such as poorly fitted dental prostheses or pointed cusps (Koebner phenomenon), thyroid dysfunction, particularly hypothyroidism ${ }^{40}$ and hepatitis $\mathrm{B}$ or $\mathrm{C}$ virus infection. Genetic, immunological, psychological (stress and anxiety) factors, systemic conditions, and viral or bacterial infections may all play a significant role in the pathogenesis of OLP ${ }^{1}$. Therefore, in addition to accurate history and pharmacological therapy, patient counseling to improve their lifestyle is indispensable. In this case report, no other contributing factors were associated with the development of the lesions.

It is important to stress the risk of malignant transformation of LP, since it is considered a lesion with potential for malignant transformation ${ }^{3,40,41}$. It has been associated with tobacco use, alcohol and hepatitis $C$ virus infection $^{42}$. Although these factors are not reported by the patient in this study, we encourage regular follow-up of patients with OLP. There is no consensus on the optimal number of annual dental visit returns, but two visits per year seem adequate and feasible ${ }^{43}$. In this case, despite the absence of factors associated with malignant transformation, returns were scheduled every 6 months due to the new treatment of the lesion. After the remission of the clinical condition, visits to the dental office took place annually. Currently, the patient is 6 years free of the disease.

To our knowledge, this is the first case report of OLP treated by the combination of calcipotriene and betamethasone. This new therapeutic approach provides a safe and effective new alternative for treating lip OLP, providing remission of the lesion after conventional therapy has failed and a consequent improvement in the patient's quality of life. However, further prospective clinical studies involving larger groups of OLP patients are required to consolidate the pharmacological protocol implemented here and to investigate possible side effects of this treatment. We did not observe any side effects resulting from the pharmacological therapy adopted or any clinical changes in OLP during the recommended treatment.

CONCLUSION

LP may appear first and / or exclusively in the oral cavity. When in lip it presents itself clinically in different ways, having relevance in dental practice because it causes aesthetic impairment and often morbidity. Knowing the different forms of treatment available gives the choice of the right therapy for each case and leads to successful treatment and improved patient prognosis. We used calcipotriol and betamethasone combination therapy to treat a case of lip-restricted OLP, with complete remission after a long follow-up. This combination of drugs is widely accepted in the treatment of PV patients, with high success rates. We believe that the similar pathogenesis between the two lesions is the reason that leads to remission responses. We suggest that calcipotriol and betamethasone combination therapy may be a new approach in treating OLP. 


\section{REFERENCES}

1. Roopashree MR, Gondhalekar RV, Shashikanth MC, George J, Thippeswamy SH, Shukla A. Pathogenesis of oral lichen planus-a review. J Oral Pathol Med. 2010;39(10):729-34.

2. Moger G, Thippanna CK, Kenchappa M, Puttalingaiah VD. Erosive oral lichen planus with cutaneous involvement in a 7-year-old girl: A rare case report. J Indian Soc Pedod Prev Dent. 2013;31:197-200.

3. Aminzadeh A, Jahanshahi G, Ahmadi M.A retrospective comparative study on clinicopathologic features of oral lichen planus and oral lichenoid lesions. Dent Res J. 2013;10(2):168-72.

4. Alrashdan MS, Cirillo N, McCullough M. Oral lichen planus: a literature review and update. Arch Dermatol Res. 2016;308(8):539-51.

5. Eisen D. The clinical manifestations and treatment of OLP. Dermatol Clin. 2003;21(1):79-89.

6. Boorghani $M$, Gholizadeh $N$, Zenouz AT, Vatankhah M, Mehdipour M. Oral lichen planus: clinical features, etiology, treatment and management: a review of literature. J Dent Res Dent Clin Dent Prospect. 2010;4(1):3-9.

7. Fraga, HF, Cerqueira NS, Ribeiro LSF, Souza SE, Paraguassú GM, Pinto FilhoJM, et al. The importance of diagnostic of oral lichen planus. J. Health Sci Inst. 2011;29(1):27-30.

8. Parashar P. Oral lichen planus. Otolaryngol Clin North Am. 2011;44(1):89-107.

9. Gonzalez-Moles MA, Scully C, Gil-Montoya JA. Oral lichen planus: controversies surrounding malignant transformation. Oral Dis. 2008;14:229-43.

10. González-Moles MÁ, Ruiz-Ávila I, GonzálezRuiz L, Ayén Á, Gil-Montoya JA, Ramos-García $P$. Malignant transformation risk of oral lichen planus: A systematic review and comprehensive meta-analysis. Oral Oncol. 2019;96:121-30.

11. Hasan, S. Lichen planus of lip - Report of a rare case with review of literature. J Family Med Prim Care. 2019;8(3):1269-75.

12. Thongprasom $K$, Luengvisut $P$, Wongwatanakij $A$, Boonjatturus C. Clinical evaluation in treatment of oral lichen planus with topical fluocinolone acetonide: a 2-year follow-up. J Oral Pathol Med. 2003;32(6):315-22.

13. Carbone M, Conrotto D, Carrozzo M, Broccoletti R, Gandolfo S, Scully C. Topical corticosteroids in association with miconazole and chlorhexidine in the long-term management of atrophic-erosive oral lichen planus: a placebo-controlled and comparative study between clobetasol and fluocinonide. Oral Dis. 1999;5(1):44-9.

14. Al-Hashimi I, Schifter M, Lockhart PB, Wray D, Brennan M, Migliorati CA, et al. Oral lichen planus and oral lichenoid lesions: diagnostic and therapeutic considerations. Oral Surg Oral Med Oral Pathol Oral Radiol Endod. 2007;103 Suppl:S25.e1-12.

15. O'Neill ID, Scully C. Biologics in oral medicine: ulcerative disorders. Oral Dis. 2013;19:37-45.

16. Thongprasom K, Prapinjumrune $\mathrm{C}$, Carrozzo $\mathrm{M}$. Novel therapies for oral lichen planus. J Oral Pathol Med. 2013;42:721-27.

17. Papp KA, Guenther L, Boyden B, Larsen FG, Harvima RJ, Guilhou JJ et al. Early onset of action and efficacy of a combination of calcipotriene and betamethasone dipropionate in the treatment of psoriasis. J Am Acad Dermatol. 2003;48(1):48-54.

18. van der Velden HM, Pasch MC, van Erp PE, van Lingen RG, Otero ME, de Boer-van Huizen $\mathrm{RT}$, et al. Treatment of plaque psoriasis with the two-compound product calcipotriol/betamethasone dipropionate versus both monotherapies: an immunohistochemical study. J Dermatolog Treat. 2010;21:13-22.

19. Singapore Lichen Planus Study Group. A randomized controlled trial to compare calcipotriol with betamethasone valerate for the treatment of cutaneous lichen planus. J Dermatolog Treat. 2004;15(3):141-45.

20. Eisen D, Carrozzo M, Bagan Sebastian JV, Thongprasom K. Number V oral lichen planus: clinical features and management. Oral Dis. 2005;11(6):338-49.

21. Farhi D, Dupin N. Pathophysiology, etiologic factors, and clinical management of oral lichen planus, part I: facts and controversies. Clin Dermatol. 2010;28(1):100-8.

22. Wagner G, Rose C, Sachse MM. Clinical variants of lichen planus. J Dtsch Dermatol Ges. 2013;11(4):309-19.

23. Nuzzolo P, Celentano A, Bucci P, Adamo D, Ruoppo E, Leuci S, et al. Lichen planus of the lips: An intermediate disease between the skin and mucosa? Retrospective clinical study and review of the literature. Int $\mathrm{J}$ Dermatol. 2016;55:473-81.

24. Xue JL, Fan MW, Wang SZ, Chen XM, Li Y, Wang L. A clinical study of 674 patients with oral lichen planus in China. J Oral Pathol Med. 2005;34(8):467-72.

25. Carrozzo M, Thorpe R. Oral lichen planus: a review. Minerva Stomatol. 2009;58(10):519-37.

26. Nico MM, Fernandes JD, Lourenço SV. Lichen Planus Affecting the Lips. J Clin Exp Dermatol Res. 2015;6:306.

27. Sugerman PB, Savage NW, Walsh LJ, Zhao ZZ, Zhou XJ, Khan A. The pathogenesis of oral lichen planus. Crit Rev Oral Biol Med. 2002;13:350-365.

28. Carbone M, Conrotto D, Carrozzo M, Broccoletti R, Gandolfo S, Scully C. Topical corticosteroids in association with miconazole 
and chlorhexidine in the long-term management of atrophic-erosive oral lichen planus: a placebo-controlled and comparative study between clobetasol and fluocinonide. Oral Dis. 1999;5:44-9.

29. Thongprasom K, Luengvisut $P$, Wongwatanakij A, Boonjatturus C. Clinical evaluation in treatment of oral lichen planus with topical fluocinolone acetonide: a 2-year follow-up. J Oral Pathol Med. 2003;32:315-22.

30.Savage NW, McCullough MJ. Topical corticosteroids in dental practice. Aust Dent J. 2005;50:S40-S44.

31. Thongprasom K, Dhanuthai K. Steriods in the treatment of lichen planus: a review. J Oral Sci. 2008; 50:377-85.

32. Larcen CG, Kristensen M, Paludan $\mathrm{K}$ et al. $1,25(\mathrm{OH}) 2-\mathrm{D} 3$ is a potent regulator of interleukin-1-induced inter- leukin-8 expression and production. Biochem Biophys Res Commun. 1991;176:1020-26.

33. Douglas WS, Poulin Y, Decroix J, Ortonne JP, Mrowietz U, Gulliver W et al. A new calcipotriol/betamethasone formulation with rapid onset of action was superior to monotherapy with betamethasone dipropionate or calcipotriol in psoriasis vulgaris. Acta Derm Venereol. 2002;82:131-35.

34. Kaufmann R, Bibby AJ, Bissonnette R, Cambazard F, Chu AC, Decroix J et al. A new calcipotriol/betamethasone dipropionate formulation (DaivobetTM) is an effective oncedaily treatment for psoriasis vulgaris. Dermatology. 2002;205:389-93.

35. Cunliffe WJ, Berth-Jones J, Claudy A, Fairiss G, Goldin D, Gratton D et al. Comparative study of calcipotriol (MC 903) ointment and betamethasone 17-valerate ointment in patients with psoriasis vulgaris. J Am Acad Dermatol. J Am Acad Dermatol. 1992;26(5 Pt 1):736-43.

36. Ramsay CA, Berth-Jones J, Brundin G, Cunliffe WJ, Dubertret L, van de Kerkhof PC et al. Long-term treatment of chronic plaque psoriasis with calcipotriol. Dermatology. 1994;189(3):260264.

37. Chuang TY, Samson CR. Clinical efficacy and safety of aug- mented betamethasone dipropionate ointment and diflo- rasone diacetate ointment for psoriasis-a multicentre, ran- domised, double-blind study. J Dermatol Treat. 1991;2:63-66.

38. Fredriksson T, Pettersson U. Severe psoriasis: oral therapy with a new retinoid. Dermatologica. 1978;157:238-44.

39. Siponen M, Huuskonen L, Laara E, Salo T. Association of oral lichen planus with thyroid disease in a Finnish popula- tion: a retrospective case-control study. Oral Surg Oral Med Oral Pathol Oral Radiol Endod. 2010;110:319-24
40. Petersen PE. Oral cancer prevention and control-The approach of the World Health Organization. Oral Oncol. 2009;45(4-5):454-60.

41.van der Waal I. Potentially malignant disorders of the oral and oropharyngeal mucosa; present concepts of management. Oral Oncol. 2010;46(6):423-25.

42. Aghbari SMH, Abushouk Al, Attia A, Elmaraezy A, Menshawy A, Ahmed MS, et al. Malignant transformation of oral lichen planus and oral lichenoid lesions: A meta-analysis of 20095 patient data. Oral Oncol. 2017;68:92-102.

43. van der Meij EH, Mast $H$, van der Waal I. The possible premalignant character of oral lichen planus and oral lichenoid lesions: a prospective five-year follow- up study of 192 patients. Oral Oncol. 2007;43(8):742-48.

\section{CONFLICTS OF INTERESTS}

The authors declare no conflicts of interests.

\section{CORRESPONDING AUTHOR}

\section{Thâmara Manoela Marinho Bezerra}

Departamento de Patologia Oral,

Faculdade de Farmácia, Odontologia e Enfermagem (FFOE)

Universidade Federal do Ceará (UFC)

60430-355 Fortaleza - CE, Brazil

E-mail: tmmbezerra@gmail.com

Received 07/04/2020

Accepted 23/10/2020 